\title{
The populist wave and global trade diplomacy besieged: a European approach to WTO reform
}

\author{
Geoffrey Allen Pigman ${ }^{1}$
}

\begin{abstract}
A transnational wave of popular anger over liberal trade and the diplomacy that facilitates it was evident in the Brexit and Trump elections of 2016. Drawing upon an understanding of how the diplomacy of international trade has undergone successive transformations over the past two centuries, this article seeks to understand how institutions that facilitate trade diplomacy, such as the World Trade Organizations, increasingly fail to meet the expectations of the global public. The article contends that excessive 'judicialization' of WTO trade diplomacy has marginalized the WTO's all-important legislative and executive functions. WTO institutional reforms are proposed to make the WTO's institutional structure more akin to that of the European Union, which has been relatively more successful at facilitating trade diplomacy with popular legitimacy.
\end{abstract}

Keywords Diplomacy · Trade · World Trade

Organization · European Union · Transformation ·

Multilateralism

\section{Introduction: populism and a crisis for global trade?}

The year 2016 can be considered an Annus horribilis for diplomacy, and particularly for the diplomacy of international trade. A wave of populist sentiment amongst voters in industrialized countries discontented with their

Correspondence to: Geoffrey Allen Pigman gapigman@protonmail.com

1 Department of Political Sciences, University of Pretoria, Pretoria, South Africa economic prospects resulted in electoral victories portending an unprecedented rise in international trade barriers. In the United States, still the largest global trading power and the driver of the diplomacy that led to the postSecond World War liberal global trading system, a majority of presidential candidates ran against liberal trade for the first time in the post-war era. The candidate who became president after winning a majority of electoral college votes (even whilst losing the popular vote), Donald Trump, ran on an aggressively economic nationalist platform threatening to withdraw the United States from major international trade agreements. Upon inauguration, Trump promptly withdrew the USA from the recently signed but yet to be ratified 12-nation Trans-Pacific Partnership (TPP12), a free trade agreement that would have comprised over $40 \%$ of global trade. In the United Kingdom, a majority of voters in England and Wales voted in sufficient numbers in a referendum on withdrawing the UK from the European Union to cause the measure to pass nationwide, setting in motion a process that is likely to result in the UK's departure from the largest and most successful trade liberalization and economic integration project in human history.

Yet 2016 was far from an unalloyed disaster in trade diplomacy terms for the European Union. Through its process of removing economic and social barriers amongst its member states over the past half century, the EU has pioneered a new model for trade diplomacy internally, which has proven increasingly effective at negotiating trade agreements with third countries and regions. Whereas the World Trade Organization (WTO)-driven multilateral trade liberalization process has stalled, with only a few elements of the last multilateral trade round, the Doha Development Agenda, completed after 17 years, the EU has taken the lead in liberalizing trade bilaterally by 
negotiating important trade deals in 2016 with Viet Nam, Canada, and Japan.

The US and UK votes of 2016 against established alliances and trading relationships, coinciding as they did, are potentially unprecedented in their implications for the diplomacy of international trade and the effects of that diplomacy upon future global economic growth and political stability. Trade diplomacy differs from trade politics and policy making in that, like all diplomacy, it is by definition relational. Diplomacy concerns establishing and maintaining relationships between two or more parties, often governments, but also international institutions, large transnational firms, civil society organizations, and groups of people. Diplomatic relationships concerning trade (as with other issue areas) have come to be structured increasingly by venues or institutions for making and enforcing agreements and resolving disputes, such as the WTO and the EU. Trade diplomacy often does not correspond with actual flows of cross-border trade and investment, which itself only comprises around a third of overall global economic activity (Roser 2014). Yet current diplomacy to implement governments' trade policies, whether leading to future agreements lowering barriers to trade and investment or not, influences business decisions affecting cross-border trade and investment flows in the present and into the future. At certain moments over the past two centuries, the diplomacy of international trade has occupied the centre of the diplomatic stage. One of those moments began in 2016. Rarely in recent decades have trade diplomacy and the politics surrounding it been so contested or had such high visibility in so many parts of the world.

The diplomacy of international trade has played a greater part in governing how the international trading system functions than is commonly credited. This article contends that the post-Second World War international trading system has lost its ability to deliver the benefits of trade effectively to global publics at a time when the global public needs those benefits as never before and at a time when global publics are able to influence trade politics and diplomacy to a hitherto unprecedented level. The populist votes of 2016 are a manifestation of this phenomenon. At a time when diplomacy involves the global public more than ever, public diplomacy as it has been understood in recent years is no longer functioning well enough, at least with respect to the crucial area of international trade, to sustain popular support for liberal trade in key industrial countries like the US and the UK. The diplomacy of successive GATT/WTO multilateral trade liberalization negotiating rounds has lost momentum because power has shifted away from the traditionally dominant trading powers (USA, EU, Japan, Canada) toward big emerging markets (China, Brazil, India), which have grown rapidly in recent decades relative to their industrial country partners, and coalitions of developing countries led by big emerging markets. This redistribution of power has progressed far enough to cause negotiations to result in stalemates rather than outcomes in which various combinations of industrial country preferences have dominated (Elsig and Dupont 2012, pp. 587-588), leading to a relative dearth of negotiated market openings for industrial country governments to present to eager constituents. At the same time, the WTO's dispute settlement mechanism has worked so well over the past two decades that it has come to function as an effective substitute for the diplomacy of multilateral rounds. This form of diplomatic 'legislating from the bench' has eroded popular support for multilateral trade liberalization at a time when it is needed more than ever, in the face of more genuine threats to employment from technological advances (Hoekman 2012, p. 744). Similarly, public opposition has increased against the arbitration model for dispute resolution known as 'investor-state dispute settlement' (ISDS) that is common in bilateral investment treaties (BITs). The ISDS arbitration model is based upon business arbitration, in which disputants select their own arbitrators, and in which rulings are not subject to any judicial review or appeal.

Almost from the time of its inception in 1995, diplomats, other practitioners, and academics have debated proposals to reform the WTO's institutional structure, its overall remit, and its institutional objectives (Hoekman 2012). Major studies of prospective WTO reforms have been produced, including a 2004 report chaired by former WTO Director General Peter Sutherland and an extensive academic study by the Warwick Commission (2007). None of the reform proposals to date have generated any real consensus on implementing WTO reforms, but arguably the impact on trade of the populist elections of 2016 may change that calculus. The purpose of this paper is not to rehearse the history of WTO reform proposals to date, but rather to make a prescriptive theoretical argument for a diplomacy-driven reform of the WTO.

To remedy the weaknesses that 'judicialization' has brought to the WTO diplomatic model, a prospective approach to reform of the WTO system already exists in the European Union. Diplomatic processes based upon the sovereignty of each EU member state have transformed the EU over six decades from a customs union into a Single European Market (SEM) in which tariffs and other barriers to trade and other economic activity between its nearly thirty member states have been removed. The diplomacy required to construct the SEM has been complex and often difficult, because it has evolved into four distinct if intertwined processes: ongoing direct (inter-governmental) diplomacy that culminates periodically in inter-governmental conferences (IGCs); legislative, executive and 
administrative institutions (the European Commission, Council, and Parliament); and a judiciary to resolve disputes (the European Court of Justice). The complex balancing between these three processes, whilst far from perfect, nonetheless addresses the challenges of transparency, legitimacy, and effectiveness for a successful open trading system much more successfully than current multilateral trade diplomacy has done. The EU's successes in trade diplomacy have been demonstrated by its ability to learn from its own internal experience to become more effective at external trade diplomacy in recent decades (Orbie 2008, p. 47).

This article proceeds first by explaining how three successive transformations in trade diplomacy have left the global trading system vulnerable to the successes and failures of judicialization. The changes that the three transformations up to this point have brought about in the global trading system and trade diplomacy now mandate a further transformation that should make the institutional structure of global trade diplomacy look more like that of the European Union. The first transformation established diplomatic processes to liberalize trade. The second transformation created institutions to stabilize that diplomatic process, and in so doing made the processes of negotiating, legislating, and managing the international trading system more durable and robust. The third transformation addressed a weakness in dispute resolution, but in so doing tipped the balance too far toward legislating from the bench, at a time when global power redistribution toward developing countries made negotiating and legislating more difficult. A fourth transformation is now needed to adjust WTO structures to restore that balance, in part by improving the functioning of the WTO's legislative and executive structures.

\section{Transformations in trade diplomacy}

There is a dynamic causal inter-relationship between trade diplomacy, on one hand, and the structure and functioning of the international trading system, on the other. During the past two centuries an ongoing process of transformation in how and why trade diplomacy is done has both shaped and been shaped by the structure and function of the international trading system. Understanding these transformations since the late eighteenth century generates an understanding both of how trade diplomacy is done today and of the strengths and weaknesses in the way the contemporary global trading system functions (Pigman 2016, 1-14) .

Three successive transformations have already taken place: liberalization, beginning in the early nineteenth century; institutionalization, beginning in the early twentieth century and accelerating after the Second World War; and judicialization, beginning in the mid-1990s when the WTO Dispute Settlement Understanding came into effect. As trade has expanded in importance as a portion of overall economic activity, trade diplomacy and the global trading system have both grown more complex. The three successive transformations in trade diplomacy thus far have produced a diplomatic system for trade that is layered, accretive, jumbled, and does not always fit together tidily (Pigman 2016, pp. 8-11).

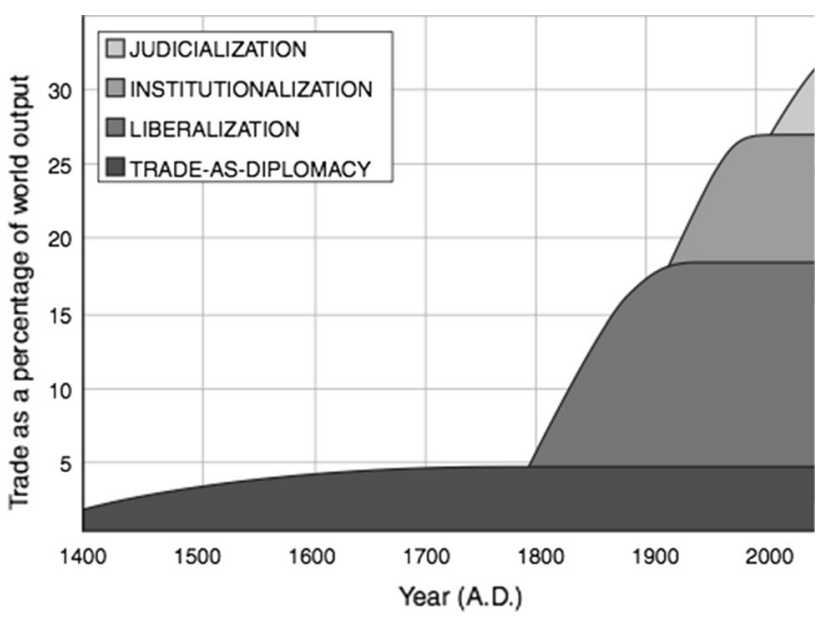

Infographic: Pigman 2016, p. 13; Data: Roser 2014.

The transformations have been accretive, in the sense that older approaches to trade diplomacy do not disappear, they merely become subordinated to a newly predominant approach. Each transformation in who diplomatic actors are, what they seek to do and how, and through which venues they operate cannot be seen to have a sharply defined beginning or end. Appearing first as harbingers and forerunners, transformation changes the global trading system over years and even decades up to the point that it passes a tipping point that differentiates the transformed system from what preceded it (Pigman 2016, pp. 9-10). The discussion that follows illustrates how these processes have taken place up to now.

Understanding how and why trade diplomacy has been transformed successively over the last two hundred years requires an understanding of the original relationship between trade and diplomacy (Pigman 2016, pp. 15-17). This first era, which can be thought of as 'trade-as-diplomacy', stretched over several millennia from the time when humans first began to seek needed goods from farther afield than their immediate surroundings and to exchange surplus items that they possessed for goods they sought. In these times, trade and diplomacy were essentially the same activity. Sharp (2009, pp. 94-95) recounts a sort of anthropological fable, replayed countless times, in which a 
tribe becomes aware of another tribe living nearby without knowing whether the other tribe poses a security threat. They leave a gift for the other tribe at an in-between location and wait to see if the other tribe leaves a gift in return. Such a process, when successful, both established diplomatic relations with an unknown or estranged other and initiated trade between them.

From these multiple, modest beginnings, trade-asdiplomacy evolved into a system of trader-diplomats engaging in state mercantilism, through which states or governments exercised power through trade. The diplomacy of gifts played an important part in the fourteenth century B.C. Amarna System in the Near East, one of the earliest documented diplomatic systems. Tribute paid by one monarch to another to show respect and affection (often reciprocated) became a form of export of surplus goods (Cohen and Westbrook 2000, pp. 1-12; Zaccagnini 2000, pp. 144-145). The story of the Silk Road connecting China to Europe over many centuries (and once again being revived by China under its current 'Belt and Road Initiative') is a quintessential narrative of trade-as-diplomacy, in which travellers such as Marco Polo and his family bringing goods to exchange also exchanged culture, politics, and knowledge (Zhang 2005; Polo 1958). By the seventeenth century trader-diplomats transported 'traded diplomats' across the Atlantic and Indian Oceans. Africans sold into slavery in the Americas and Malays enslaved in southern Africa functioned as diplomats, albeit involuntarily, by bringing their culture to a different society and in so doing changing recipient societies. (Sparks 2014, pp. 1-67). Trade-as-diplomacy thus can be understood to be the progenitor of both modern diplomacy and modern state power over economic activity in the form of mercantilism. By the eighteenth century, prohibitive tariffs, trade prohibitions, and economic blockades had become favored diplomatic instruments both short of and during war for governments of major powers such as France and England. But these practices, which culminated in the ruinous economic warfare of the Napoleonic Wars, carried out against the backdrop of an accelerating Industrial Revolution, illustrated the fundamental weakness of tradeas-diplomacy. Once trade restrictions as a primary instrument of diplomacy and statecraft became the norm, trade could only be expected to generate limited economic growth (Crouzet 2002, 2005). At a time when citizenries would begin to expect governments to deliver ever more economic welfare as a price for popular support, the rôle of trade in economies and of trade diplomacy would have to change.

By the time of the Congress of Vienna in 1815 , which heralded the return to a peacetime Europe, the need for a transformation in trade diplomacy was fairly straightforward. Industry was generating so many surplus goods in states like Britain, in which the Industrial Revolution was most advanced, that the need for more trade exceeded the need for trade-as-diplomacy, at least in its latter form of mercantilist trade barriers. Workers left English farms in droves to take up factory work in fast growing urban areas, as Polanyi (2001 [1944]) observed, where they needed to buy food on factory wages. As states industrialized, leaders of many governments realized they could no longer afford not to promote trade if they wished to retain popular support from a broadening political franchise. This realization engendered a new approach for policy makers and diplomats: to see trade differently, as a positive sum activity generating economic value greater than its utility for state power. As British trade liberalization campaigners Richard Cobden and John Bright contended, trade promoted peace and stability, which enabled states to accumulate power through economic growth rather than war and conquest (Edsall 1986). These major public campaigns for trade liberalization, first in Britain and then across Europe, were indicative of the growing part that publics and public opinion would play in trade policy and diplomacy going forward.

The emblematic method or instrument of trade diplomacy that this liberalizing transformation heralded was the bilateral trade liberalization treaty mandating specified tariff reductions and the extension of those tariff cuts to third countries under what became known as the Most Favored Nation (MFN) principle. The best example of the bilateral liberalization treaty was the Anglo-French 'Cobden-Chevalier' Commercial Treaty of 1860 . Negotiated by Richard Cobden and his French counterpart Michel Chevalier at a time when Anglo-French military tensions were high, the treaty reduced French tariffs on industrial commodities such as coal, coke, iron and steel by up to one half in return for reductions in British revenue duties on wine and spirits (Dunham 1930; Kindleberger 1975). In addition to stimulating exports of major commodities of each country, the treaty enshrined peace and security between Britain and France (Iliasu 1971). Moreover, it stimulated the signing of a network of between 50 and 60 such tariff reduction treaties between European countries that spread benefits rapidly to third countries via the MFN principle, lowering average tariffs across Europe by $50 \%$ over the decade following the Cobden-Chevalier Treaty (Mallet 1905, p. 60). This process constituted a sort of 'protoGATT' (General Agreement on Tariffs and Trade), a multilateral trade liberalization outcome, 80 years before the actual GATT was signed. The main weakness of the bilateral, tariff cuts-plus-MFN liberalization treaty system was that the treaties were of fixed duration, expiring after $10-12$ years and requiring renewal or renegotiation. Treaty expirations permitted domestic opponents of liberal trade to seek tariff increases, therein eroding already achieved 
trade gains. The period between 1870 and the onset of the First World War in 1914 was characterized by gradually rising tariffs and other trade barriers, an upsurge in nationalist political sentiments, and periodic trade wars between some European powers, all of which fuelled support for militarization as Europe slid toward war (Conybeare 1987).

Precursors of a second transformation in trade diplomacy that would institutionalize the liberalization in trade relations that the bilateral treaties had brought about appeared as early as the 1870 s, as ideas of negotiating a multilateral tariff convention in Europe were debated in France and England. Although the debates of the 1870s did not bear fruit, multilateral talks began in the 1880s to end the common practice of governments paying export subsidies to sugar producers. These negotiations eventually culminated in the signing of the Brussels Sugar Convention of 1902. The convention established the Permanent Sugar Commission, the first multilateral institution governing trade in a single commodity, sugar. The Commission was tasked with enforcing treaty prohibitions on paying export bounties on sugar (Pigman 1997). Hobbled like its bilateral predecessors by fixed duration, the convention was rendered moot by the outbreak of the First World War. It took that conflict, the destructive economic nationalism of the interwar period, and the carnage of the Second World War to drive the major global trading powers to negotiate a different and more durable approach to trade liberalization. This transformation, once fully fledged, resulted in the establishment of permanent multilateral and regional trade organizations like the General Agreement on Tariffs and Trade and the European Union to serve as host venues for trade diplomacy, thereby perpetuating gains from trade liberalization.

The GATT, signed in 1947 initially by 23 countries, committed treaty signatories to basic liberal trade rulesMFN and national treatment-plus successive multilateral trade liberalization negotiating rounds and dispute settlement procedures (Pollard 1981, p. 319). Unlike prior agreements, GATT membership was permanent unless a government formally withdrew, so no domestic political expectation of the treaty's expiration (and so opportunity for renegotiation) was built in. Hence, negotiated gains in the GATT's multilateral trade rounds were seen by all parties as locked in. The GATT negotiators intended that membership would be progressively more inclusive. Hence, as member nations decolonized, mechanisms in the agreement facilitated the joining of newly independent former colonies. GATT Part IV, negotiated in the early 1960 s, granted special and differential treatment to developing countries that relieved them of the obligation to meet GATT liberalization disciplines on the same timetable as industrial states (Curzon 1965, pp. 247-248). Ironically, the GATT Secretariat, the first permanent institution for trade diplomacy, was itself constituted provisionally, pending the ratification of a second treaty, the 1948 Havana Charter that would have established a formal International Trade Organization (ITO) (Jackson 1990). The Havana Charter was not ratified by the US Congress or UK Parliament owing to domestic political conditions, but the provisional GATT Secretariat functioned efficiently as an institution hosting the diplomatic venue for trade liberalization right up until the 1994 Treaty of Marrakech incorporated the GATT into the World Trade Organization from 1995.

In its 70 years of operation, the GATT-WTO system has generated multiple gains in how, by whom, and for what purposes trade diplomacy is undertaken. Participation has broadened dramatically, as membership has expanded to around 160 countries, with most of the remaining sovereign states in a queue to join. The range of trade issues subject to liberalization disciplines has expanded from tariffs to non-tariff barriers (NTBs) and 'behind the border' regulatory barriers such as government procurement codes and sanitary and phytosanitary standards (SPS), and later traderelated intellectual property provisions (TRIPs), trade-related investment measures (TRIMs), and trade in services. Regional trade integration and liberalization institutions, sanctioned under the GATT, developed to be just as robust, most notably in Europe, as the European Economic Community evolved into the EU, but also elsewhere in regional trade institutions such as the North American Free Trade Agreement (NAFTA), MERCOSUR in South America, the Southern African Development Community (SADC), and the Association of South East Asian Nations (ASEAN). This reinforced a popular narrative that regional trade integration was a 'stepping stone' rather than a 'stumbling block' to multilateral trade liberalization (Destler 2005, pp. 193-230; Bhagwati 2008).

The GATT-WTO diplomatic system has been in a sense a victim of its own success. The increased trade that GATT-driven trade liberalization at least in part begat in turn contributed to the catching up of rapidly developing countries (first the 'Asian Tigers' in the 1980s-Korea, Taiwan, Singapore, Hong Kong-and then the BRICS in the 2000s-Brazil, Russia, India, China, South Africa) and the increased diplomatic competition that this leveling of the economic playing field implied. The primary weakness of the GATT system that was evident by the 1980s was that the GATT's dispute settlement mechanism was slow and easily short-circuited by powerful states that did not wish to accept a judgment against them. This perception of weakness was amplified by the fact that disputes were becoming more common as states in the international system became more diverse and business interests diverged. Exporting industries in fast-growing developing 
countries clashed increasingly with import-competing 'sunset' industries in industrial economies. Amongst the other ills that beset the GATT by the late 1980s, governments began to see regional and bilateral trade liberalization agreements, also known as preferential trade agreements (PTAs), as an alternate route to improving dispute settlement. Negotiators increasingly incorporated dispute settlement mechanisms into PTAs, offering disputants a choice of venue (PTA or GATT/WTO) for resolving trade conflicts. Moreover, in each PTA, complex and restrictive rules of (non-PTA) origin for the components of products eligible for barrier-free movement had the effect of weaving a tangled web of trade discrimination that led them to be more about diverting trade to within PTAs rather than creating trade between PTAs and the outside world. This tangled web, in which the GATT MFN principle has come to mean ever less, has been referred to disparagingly by Bhagwati (2008) as a 'spaghetti bowl' undermining non-discriminatory multilateral trade practices. Hence, what had been seen for a time as virtuous competition between multilateral and regional liberalization began to be seen as undermining multilateral trade liberalization.

This major arguable weakness in how trade diplomacy operated precipitated a third transformation that would bring major change to the global trading system, tipping trade diplomacy from an environment where negotiating liberalization was not difficult, but enforcement was weak to a 'judicialized' setting where negotiation virtually ceased and the locus of decision making shifted to the Dispute Settlement and Appellate Bodies (Pigman 2016, pp. 196-216). This third transformation came about as result of effort to perfect or at least improve trade liberalization institutions in the GATT Uruguay Round of multilateral negotiations over the period 1986-1994, which led to the Treaty of Marrakech. That treaty created the WTO as a full blown institution like the International Monetary Fund and World Bank, with full binding legal obligations of membership. In order to join the WTO, prospective member states must accept the WTO's acquis communautaire, or body of settled law, in its entirety just as new members of the EU must accept the EU's acquis. Accession negotiations take WTO entrants an average of 19 years.

One of the biggest fixes that the Treaty of Marrakech gave the WTO was a stepped up Dispute Settlement Understanding, making the process more like a full blown judicial process, accelerating the timetable for the hearing of disputes, and for the first time creating an Appellate Body composed of full time jurists to hear appeals of panel decisions. Crucially, the reforms made implementation of judgements compulsory, whereas under the 1947 GATT a judgement would only be implemented if all parties to a dispute consented (Bernauer et al. 2012; Matsushita 2012). The WTO DSU in a sense emulated the European Communities (later European Union), which had already been operating a judicial model that recognized the distinct sovereignty of member states but nonetheless made enforcement of judgements in disputes obligatory.

The WTO's stepped up DSU proved its worth from the start: in the first 15 years of the WTO's operation, over 400 cases were brought to the WTO for resolution, in contrast to only 300 cases over the whole 47 years of operation of the GATT's dispute settlement process (Evans and Shaffer 2010). Moreover, only 125 of the 400 cases filed required a panel investigation, meaning that the process facilitated the parties undertaking to negotiate a direct resolution of the dispute in a large majority of cases rather than resorting to the DSU's institutional process of judicialized diplomacy. The importance of the WTO DSU to trade diplomacy has established a new norm for diplomatic practice: the WTO itself, as well as universities and big global law firms with international trade practices, are now training legions of trade lawyers, particularly from developing countries, in how to use the system (Pigman 2016, pp. 208-210). Big emerging markets like China (which only joined the WTO in 2001) and Brazil have learned rapidly how to use the DSU to their advantage (Liyu and Gao 2010, pp. 159-160; Shaffer et al. 2010, pp. 91-92). Although it may not have been intended by GATT Uruguay Round negotiators devising rules for the new dispute settlement process, the common law principle of stare decisis, or force of legal precedent, has taken hold and become a norm in the DSU. Over 20 years, panel and Appellate Body rulings have built up a body of case law to which subsequent panelists and Appellate judges refer in making judgements.

Once again, trade diplomacy can be faulted for being the victim of its own success. On one hand, the WTO's acquis communautaire and stepped up DSU has made rule observance and enforcement much stronger. But on the other, it has had the effect of making the DSU the primary site of WTO trade diplomacy. Governments now choose on behalf of their domestic constituents to let bigger conflicting trade issues be negotiated or adjudicated as and when disputes come up, rather than negotiating directly to seek agreement before conflicts arise. The last GATT/ WTO multilateral round, the Doha Development Agenda (DDA), was launched in 2001 but unlike all the previous multilateral rounds reached no comprehensive conclusion. Topical agreements have been concluded on only small portions of the overall DDA agenda (e.g. the 2015 Trade Facilitation Agreement). As a result, the WTO's dominance as the primary venue for trade liberalization diplomacy is being eroded. Since the turn of the twenty-first century, there has been a surge in new regional, plurilateral, and bilateral trade integration and liberalization 
negotiations, ranging from bilateral deals between major industrial powers, such as the recently signed Canada-EU Comprehensive Economic and Trade Agreement (CETA), to regional agreements including industrial and developing countries, such as the now 11-nation Trans-Pacific Partnership (TPP-11), to plurilateral and regional pacts amongst developing countries, such as the complex network of intra-African trade agreements aimed at creating the African Union-wide Comprehensive Free Trade Area by the early 2020s. Bhagwati's feared spaghetti bowl of trade deals marches on apace, amidst no indications of widespread enthusiasm for reviving the WTO-driven multilateral liberalization process. The spaghetti bowl of PTAs creates the risk that WTO-level standards for open trade between members will bring about the least liberal of trading relationships, the opposite of their original intent.

In the meantime, WTO dispute settlement panels hear cases, the Appellate Body hears appeals, and existing trade rules already agreed are enforced. Jurists on the Appellate Body can and do 'legislate from the bench' by interpreting and extending WTO rules at the margin. However, the DSU alone is not equipped to address major unresolved issues in conflict that affect trade, such as the differential needs of developing countries in the global trading system or the potentially adverse impact of behind-the-border regulations on trade flows. When domestic political systems become politically 'deadlocked', the judiciary can be forced to assume the decisive function in government, creating an imbalance in which popular preferences democratically articulated are sidelined. The WTO today finds itself in an analogous position of imbalance between legislative and executive functions in its diplomacy (negotiating trade agreements and monitoring their implementation) and the judicialized diplomacy of dispute resolution. The risk therein to the global trading system is that WTO may become marginalized, reduced to a technical organization charged with enforcing a set rulebook for trade, up until the time that member governments decide it is no longer in their interest to comply. This prospective threat has already been mooted by the Trump administration's notoriously protectionist US Trade Representative Robert Lighthizer, who has criticized the Appellate Body and already threatened to ignore decisions he does not consider to be in the interest of the US (Elsig et al. 2017). In a diplomatic sense the WTO risks becoming brittle. Up to this point, the WTO has not faced the threat of member state withdrawals, as most of the remaining 30-odd countries not yet members still seek actively to join. Yet given a suitable trigger, that could change rapidly (even setting aside the hostile attitude of President Trump). Evidence of public opposition to excessive judicialization of trade diplomacy can also be seen in broad criticism of investor-state dispute settlement (ISDS) mechanisms written into bilateral investment treaties (BITs) and some PTAs. Civil society organizations have been so effective in opposing ISDS, which permits private investors to bring complaints against governments directly, that the European Union has developed a new type of professionally staffed investment court with appellate review that is included in CETA and the EU-Viet Nam free trade agreement.

\section{The European Union diplomatic system and multilateral trade governance}

Up to now, when weaknesses in prevailing modes of trade diplomacy have been unable to address major challenges facing the global trading system, it has precipitated a new transformation. Each transformation up to now-liberalization, institutionalization, and judicialization-has been prefigured by diplomats' earlier attempts to innovate change in response to pressing needs, as when the CobdenChevalier Treaty system prefigured the GATT by 80 years, or when the GATT dispute settlement mechanism prefigured the more successful WTO DSU. A mode of conducting trade diplomacy that prefigures a transformation that would overcome the shortcomings of today's judicialized WTO diplomacy by righting the balance between legislation and adjudication can be seen in the European Union. The EU is a diplomatic system, in that it has been constructed through diplomatic processes by sovereign member states (Hocking and Smith 2011). The EU has evolved as a diplomacy-based model for governance of international trade through the taking of decisions collectively. As Woolcock (2012, pp. 27-28) puts it:

With due respect to size, growth and power of nonWestern economies, the modern diplomatic system based on notional sovereign equality of states can be said to have evolved in Europe. Now Europe, only somewhat intentionally, has contributed a diplomatic model for governing global trade.

In order to command enough popular support to survive and function successfully, the EU has had to reconcile the diplomatic principle of sovereignty of its member states with good governance principles of legitimacy, effectiveness, and transparency. These principles are by nature bound to be in tension, and the EU has a far from perfect record in balancing them. The EU's legitimacy continues to rest on treaty-based relations between its member states, which European publics have continued to value. It is no coincidence that citizens of some EU states rejected a proposed EU 'constitution', which was perceived as centralizing power at the expense of member state sovereignty, at the ballot box in 2005 (Dinan 2017, pp. 27-28). 
In order to balance these principles, the EU has developed a novel, diplomatic institutional structure of governance built upon member state sovereignty. The Commission, a technocratic, professionally staffed body, drafts and administers legislation and regulation; the Council comprises the member states, approves legislation and makes foreign policy; the Parliament, directly elected by the citizenry of the EU, also approves legislation, giving democratic legitimacy to EU rules; and the judiciary adjudicates EU law that supervenes member state law. As it has evolved, this institutional structure has facilitated the diplomatic negotiation of rules that promote common interests between sovereign actors that have very divergent constituencies, a fundamentally different legislative task from aggregating and reconciling sub-national interests through domestic legislation. When disputes arise, the European Court can resolve them efficiently without having to legislate excessively from the bench. Although still criticized for its 'democratic deficit', in fact the EU has worked to accommodate the rising European public demand for democratic accountability by granting ever greater powers to the European Parliament to approve legislation and budgets, by reducing secrecy in the European Commission, and by communicating more broadly and effectively to member state populations.

What evidence exists that the European Union has succeeded, or is viewed as having succeeded, in creating a better approach to trade diplomacy? Orbie (2008) and Woolcock (2012) both contend that the EU has gained invaluable experience though undergoing its own process of creating and implementing the Single European Market (SEM). Orbie (2008, pp. 36-37), for example, points out that the necessity of addressing behind-the-border regulatory issues in implementing the SEM gave the EU first mover advantage in shaping how regulations might be harmonized, which in turn has enabled the EU's model to be used as a starting point when the same issues have been taken up at the WTO. Whether or not it has been the EU's conscious intention to 'export' its approach to regulatory harmonization, certain non-EU states have already chosen to conform some regulations to facilitate access to the SEM for their goods and services. Woolcock (2012, pp. 15-16) argues that the EU diplomatic system addresses the need to aggregate both interest group and member state preferences effectively on issues where the EU has exclusive competence. For issues where European treaties divide competence between the EU and member states, the process of specialist Council decision making addresses the aggregation problem effectively. These measures have been important for the EU in meeting the once neglected but growing interests of exporting firms, trade unions, and consumers, as well as members of the public who may not understand that they have an interest in trade or how, to see the major contested issues negotiated diplomatically and to have a voice (if they wish) in that process (Orbie 2012, p. 41). Increasing demands for such transparency and accountability in diplomatic systems as much as within domestic politics are at the core of the rise of what Bruce Gregory has described as 'diplomacy's public dimension'. The 'Battle of Seattle' over the WTO's proposed launch of a new multilateral round in 2000 heralded the public's full critical engagement with trade diplomacy, but EU experience has been able to turn demands for accountability to their advantage. The EU's expansion of the rôle of the European Parliament has enabled European Commission negotiators to employ a 'tied hands' strategy when negotiating trade agreements with third countries (Orbie 2012, p. 42).

Orbie (2008, pp. 62-63) also makes the argument that the EU's institutional arrangements for trade diplomacy, in which much authority over regulatory issues is delegated to the Commission, play an important part in promoting a liberal trade agenda. '(T)he Union is institutionally designed to promote negative integration and market-enhancing policies rather than positive integration and redistribution,' he argues, making the EU better at liberalizing multilaterally rather than using trade policy to advance a broader normative policy agenda. If Orbie is correct, adopting an EU reform model for the WTO may promote one vision of what an effectively functioning WTO would achieve rather than another. Yet Orbie and Woolcock alike credit the EU for continuing to work toward achievements in normative trade policy and diplomacy as well.

EU shortcomings notwithstanding, the broader point of this argument here is that an EU diplomatic model would serve the WTO significantly better than its current institutional structure. In rough strokes, what would such a reform look like? A place to start would be to move away from the GATT-WTO model of epically huge, long-term multilateral trade liberalization rounds as the core approach to legislative diplomacy. The quiet end of the Doha Development Agenda suggests that either Bhagwati's 'bicycle theory' of trade liberalization (the bicycle must move forward or else it falls flat) was never correct, or else the bicycle has fallen over, and now new transport must be found. Diplomacy in the EU, and for that matter most of the rest of diplomacy, happens on an everyday basis: communicating about interests, mediating differences, resolving disputes, negotiating better coöperation. The WTO Secretariat is already incipiently equipped to take on this executive function, through processes such as the Trade Policy Review, under which they monitor members' trade policies on an ongoing basis, much as the European Commission monitors member states' compliance with EU regulations. The WTO Secretariat could be remodelled as 
the Global Trade Commission, the legitimacy of which could be boosted by the selection of commissioners by member states to run directorates (e.g. enlargement, external relations, regulatory harmonization). Meeting the transparency and accountability mandate could be achieved by creating a Global Trade Parliament, an idea already proposed by others (Hoekman 2012, pp. 756-757), that would be comprised either of directly elected representatives or teams or of sitting member country parliamentarians. Building upon networked parliamentary consultations already hosted by the Inter-Parliamentary Union and the European Parliament in Geneva and at WTO ministerials, such a standing Parliament would provide a more open mechanism for interests to petition on behalf of their agendas. It would also give greater legitimacy to a legislative process in which liberalization or normative policy objectives could be enacted on an everyday basis, rather than as part of a now all but impossible to achieve multilateral round. A parliamentary body would also enable implementation of a consociational mechanism for representing transnational firms and civil society organizations without undermining state sovereignty. The Commission and Parliament would work together diplomatically to legislate on an ongoing basis.

A revised WTO Council of member states' trade ministers would approve legislation, preserving the crucial sovereignty of states as WTO constituent members. The Council could meet through biennial ministerials, as occurs today, unless a different arrangement were preferred. If voting were to become the norm in a reformed WTO rather than the current informal consensus approach, it would be in the WTO's interest to adopt some form of qualified majority voting (QMV) that would take into account the size and trade volumes of states whilst protecting the interests of the smallest and poorest members (Hoekman 2012, p. 752). Ideally such a voting system would look more like the EU's relatively successful structures of QMV than like the US Electoral College, which has played such a capricious rôle in recent presidential elections by valuing votes in different states so unequally. Such a system would enable the diplomatic rulebook for global trade to be maintained and, when required, revised on an ongoing basis. The need to reach a political 'grand bargain' balancing members' interests on every issue in the multilateral rounds would be replaced by members trading support on issues intertemporally. To make major changes and to approve changes to the WTO founding documents, the WTO could hold an Inter-Governmental Conference (IGC) as the EU does on an extraordinary basis.

What incentives do major WTO stakeholders have to embrace this kind of transformational reform? Politics at the WTO today has largely reached a stalemate: big emerging markets states (BRICS, plus others such as
Mexico, Indonesia, Nigeria, and Turkey [MINT]) have accumulated enough power to block the old 'Quad' (US, EU, Canada, Japan) from achieving their major DDA objectives, as the failure to reach agreement on three of the four 'Singapore Issues' (government procurement, investment, competition policy) sought by industrial countries attests, but not enough to advance a different agenda (e.g. normative trade policies) (Narlikar and Wilkinson 2004). However, big emerging markets, in particular China, and less developed countries as well, may find themselves excluded from trade liberalization gains to the extent that they do not get to participate in major plurilateral agreements like the Japan-led TPP-11. Industrial countries have adapted to the WTO stalemate by focusing on bilateral, regional, and plurilateral agreements to increase trade and open markets. Importantly, however, both industrial and developing countries stand to lose as public antipathy to trade liberalization grows, fanned by populist politicians seeking to advance their own electoral prospects. Constituents in developing countries seeking economic reforms in their domestic political systems look for more than stalemate at the WTO. Reform on the EU model would offer a real chance to achieve more: shifting diplomacy between sovereign member actors away from multilateral 'all-or-nothing' rounds toward everyday legislating could allow for more cross-issue and cross-bloc negotiating tradeoffs, for example between trade and security or trade and development issues.

Further, the EU reform model has a potential powerful new champion: the European Union itself. Even as the Trump administration in the United States has given clear indications of wishing to withdraw from global trade diplomacy, the EU has stepped up its participation on the global trade stage, applying lessons learned from the creation of the SEM and modeling regulatory harmonization. The EU's diplomatic system has generated a large number of experienced negotiators, whom the EU would like to put to use in expanding the global trade diplomacy remit to include investment and competition, as well as social and environmental issues, all of which would be beneficial (Orbie 2008, p. 47). As popular support for the EU has rallied after the 2016 'Brexit' vote, an opportunity exists for EU diplomats to act more assertively to advance a WTO reform agenda.

\section{Conclusions}

The objective of this paper has not been to conduct a critical review of the series of proposals over the past decade for reform of the WTO, which in any event space does not permit. Rather, the argument has sought to generate and ground a theoretically based vision for a reformed 
WTO based on the successful trade diplomacy of the European Union. The three successive transformations in trade diplomacy that have occurred already have resulted in a global trading system of newer, dominant approaches overlaying each of the older approaches. Even in an age dominated by judicialized trade diplomacy, trade-asdiplomacy still takes place occasionally, as when Chairman Mao sent a large gift of considerable value, two giant pandas, to President Nixon in 1971. Moreover, as postpositivist scholars would affirm, despite the achieved liberalization and integration gains from successive transformations, the trajectory of trade liberalization and economic integration is far from a smooth vector, either regionally or globally. US Trade Representative Lighthizer has openly longed for a return to the pre-WTO GATT DSM, under which any party to a dispute could block a panel ruling's implementation (Elsig et al. 2017). Amongst Trump's NAFTA renegotiation objectives is a provision under which the entire agreement would expire every five years, vitiating the institutional innovation of making trade agreements presumptively permanent and thus discouraging domestic political interests from undoing trade liberalization diplomacy at regular intervals (Pigman 2016, pp. 130-131).

Looking ahead, it is significant that past transformations in trade diplomacy have taken place organically, without self-reflection by scholars or diplomats. Hence, proposing the desirability of a fourth transformation itself changes how transformation may take place. Europe's own model of conducting trade diplomacy potentially offers much to the broader global community. However, communicating with the global public about trade and diplomacy in such a way as to rally popular support is likely to be the greatest challenge to realizing that potential. That public diplomacy challenge should not deter putative reformers, when the alternative is a heightened potential for the collapse of liberal trade and its institutions brought on by populist opposition to trade, which would guarantee an international trading system made more in 1930s Berlin than 1930s Ottawa. Instead of a benign regionalism echoing its supporters' aspirations for the short-lived Ottawa System of Commonwealth trade preferences, inaction risks the emergence of a trading system based on autarky, bilateral trade balancing, of unequal agreements at the end of a gun barrel. Toxic populism played out on the diplomatic stage only reifies a world of nationalist states whose populations have too often been open, initially at least, to rule by budding autocrats already too familiar to the contemporary global public.

\section{References}

Bernauer, Thomas, Manfred Elsig, and Joost Pauwelyn. 2012. Dispute Settlement Mechanism-Analysis and Problems. In The Oxford Handbook on the World Trade Organization, ed. Amrita Narlikar, Martin Daunton, and Robert M. Stern, 485-506. Oxford: Oxford University Press.

Bhagwati, Jagdish. 2008. Termites in the Trading System; How Preferential Agreements Undermine Free Trade. Oxford: Oxford University Press.

Cohen, Raymond, and Raymond Westbrook. 2000. Introduction: The Amarna System. In Amarna Diplomacy: The Beginnings of International Relations, ed. Raymond Cohen and Raymond Westbrook, 1-12. Baltimore: The Johns Hopkins University Press.

Commission, Warwick. 2007. The Multilateral Trade Regime: Which Way Forward?. Coventry: University of Warwick.

Conybeare, John A.C. 1987. Trade Wars; the Theory and Practice of International Commercial Rivalry. New York: Columbia University Press.

Crouzet, François. 2002. Mercantilism, War and the Rise of British Power. In Two Hegemonies; Britain 1846-1914 and the United States 1941-2001, ed. Patrick Karl O'Brien, and Armand Clesse, 67-85. Aldershot: Ashgate.

Crouzet, François. 2005. Wars, Blockade, and Economic Change in Europe, 1792-1815, Economic History, vol. 24, No. 4, December 1964, pp. 567-588, reprinted in Kevin H. O'Rourke, ed., The International Trading System, Globalization and History, Volume I. Cheltenham: Edward Elgar, pp. 151-172.

Curzon, Gerard. 1965. Multilateral Commercial Diplomacy; The General Agreement on Tariffs and Trade and its Impact on National Commercial Policies and Techniques. London: Michael Joseph.

Destler, I.M. 2005. American Trade Politics, 4th edn. Washington: Institute for International Economics.

Dinan, Desmond. 2017. Crises in EU History. In The European Union in Crisis, ed. Desmond Dinan, Neill Nugent, and William A. Paterson, 16-32. London: Palgrave Macmillan.

Dunham, A.L. 1930. The Anglo-French Treaty of Commerce of 1860 and the Progress of the Industrial Revolution in France. Ann Arbor: University of Michigan Press.

Edsall, Nicholas. 1986. Richard Cobden, Independent Radical. Cambridge: Harvard University Press.

Elsig, Manfred, and Cédric Dupont. 2012. Persistent Deadlock in Multilateral Trade Negotiations: The Case of Doha. In The Oxford Handbook on the World Trade Organization, ed. Amrita Narlikar, Martin Daunton, and Robert M. Stern, 587-606. Oxford: Oxford University Press.

Elsig, Manfred, Mark Pollack, and Gregory Shaffer. 2017. Trump is Fighting an Open War on Trade. His Stealth War on Trade may be Even More Important. The Washington Post. https://www. washingtonpost.com/news/monkey-cage/wp/2017/. Accessed 27 Sept 2017.

Evans, David, and Gregory C. Shaffer. 2010. Introduction. In Dispute Settlement at the WTO; The Developing Country Experience, eds. Gregory C. Shaffer and Ricardo Melendez-Ortiz, 1-17. Cambridge: Cambridge University Press.

Hocking, Brian, and Michael Smith. 2011. An emerging diplomatic system for the EU? Frameworks and Issues. Cuadernos Europeos de Deusto 44: 19-42.

Hoekman, Bernard. 2012. Proposals for WTO Reform: A Synthesis and Assessment. In The Oxford Handbook on the World Trade Organization, ed. Amrita Narlikar, Martin Daunton, and Robert M. Stern, 775. Oxford: Oxford University Press. 
Iliasu, A.A. 1971. The Cobden-Chevalier Commercial Treaty of 1860. Historical Journal 14 (1): 67-98.

Jackson, John H. 1990. Restructuring the GATT. London: Pinter Publishers Ltd.

Kindleberger, Charles P. 1975. The Rise and Fall of Free Trade in Western Europe, 1820-1875. Journal of Economic History 35 (1): $20-55$.

Liyu, Han, and Henry Gao. 2010. China's Experience in Utilizing the WTO Dispute Settlement Mechanism. In Dispute Settlement at the WTO; The Developing Country Experience, eds. Gregory C. Shaffer and Ricardo Melendez-Ortiz, 137-171. Cambridge: Cambridge University Press.

Mallet, Bernard. 1905. Sir Louis Mallet. London: James Nisbet \& Co., Ltd.

Matsushita, Mitsuko. 2012. The Dispute Settlement Mechanism at the WTO: The Appellate Body-Assessment and Problems. In The Oxford Handbook on the World Trade Organization, ed. Amrita Narlikar, Martin Daunton, and Robert M. Stern, 507-534. Oxford: Oxford University Press.

Narlikar, Amrita, and Rorden Wilkinson. 2004. Collapse at the WTO: a Cancun post-mortem. Third World Quarterly 25 (3): 447-460.

Orbie, J. 2008. The European Union's Role in World Trade: Harnessing Globalisation? In Europe's Global Role; External Policies of the European Union, ed. Jan Orbie. Abingdon: Routledge.

Pigman, Geoffrey Allen. 1997. Hegemony and Trade Liberalization Policy: Britain and the Brussels Sugar Convention of 1902. Review of International Studies 23: 185-210.

Pigman, Geoffrey Allen. 2016. Trade Diplomacy Transformed: Why Trade Matters for Global Prosperity, 2nd edn. Raleigh: Lulu Press.

Polanyi, Karl. (2001 [1944]). The Great Transformation, 2nd edn., Boston: Beacon Press.

Pollard, Sidney. 1981. Peaceful Conquest. Oxford: Oxford University Press.

Polo, Marco. 1958. The Travels of Marco Polo. (trans: Latham, R.E.) Harmondsworth: Penguin Books, Ltd.
Roser, Max. 2014. International Trade, Our World In Data, https:www.ourworldindata.org/data/global-interonnections/inter national-trade/. Accessed 4 Feb 2015.

Shaffer, Gregory C., Michelle Ratton Sanchez Badin, and Barbara Rosenberg. 2010. Winning at the WTO: The Development of a Trade Policy Community Within Brazil. In Dispute Settlement at the WTO; The Developing Country Experience, eds. Gregory C. Shaffer and Ricardo Melendez-Ortiz, 21-104. Cambridge: Cambridge University Press.

Sharp, Paul. 2009. Diplomatic Theory of International Relations. Cambridge: Cambridge University Press.

Sparks, Randy J. 2014. Where the Negroes Are Masters; An African Port in the Era of the Slave Trade. Cambridge: Harvard University Press.

Wilcox, Clair. 1949. A Charter for World Trade. New York: Macmillan.

Woolcock, Stephen. 2012. European Union Economic Diplomacy; The Role of the EU in External Economic Relations. Farnham: Ashgate.

Zaccagnini, Carlo. 2000. The Interdependence of the Great Powers. In Amarna Diplomacy: The Beginnings of International Relations, eds. R. Cohen and R. Westbrook, 141-153. Baltimore: The Johns Hopkins University Press.

Zhang Yiping. 2005. Story of the Silk Road. Beijing: China Intercontinental Press.

Geoffrey Allen Pigman Heads a global trade and strategy consulting practice. Research Associate and Visiting Fellow, Department of Political Sciences, University of Pretoria, Research Associate, Institute for Global Dialogue (Pretoria, South Africa). His principal areas of research are contemporary diplomacy (including trade, public and sports-diplomacy), international trade politics, and foreign economic policy making. Publications include Trade Diplomacy Transformed: Why Trade Matters for Global Prosperity (1st edn. Palgrave Macmillan 2015, 2nd edn. Lulu Press 2016), Contemporary Diplomacy (Polity Press 2010), The World Economic Forum: A Multistakeholder approach to global governance (Routledge 2006). 